\title{
O Dever da Parte Sucumbente de Indenizar a Parte Vencedora pelos Prejuízos com o Processo. ou, é possível Ganhar sem Perder?
}

\section{The Duty of The Succumbing Party to Indemnify the Party Harmed by the Losses with the LAWSUIT. ALTERNATIVELY, IS IT POSSIBLE TO WIN WITHOUT LOSING?}

\section{El Deber del Sucumbente de Indemnizar al Ganador de las Pérdidas con el Proceso. o, ies posible Ganar sin Perder?}

Gilberto Fachetti Silvestre* Felipe Sardenberg Guimarães Trés Henriques

1 Introdução. 2 Pagamento de honorários contratuais pela parte sucumbente em decorrência do exercício abusivo do direito de petição. 3 Critérios para fixação dos honorários contratuais. 4 Análise qualiquantitativa dos julgados do Superior Tribunal de Justiça. 5 Conclusão. Referências.

\footnotetext{
* Professor do Departamento de Direito e do Programa de Pós-Graduação em Direito (Mestrado em Direito Processual) da Universidade Federal do Espírito Santo (UFES); Doutor em Direito Civil pela Pontifícia Universidade Católica de São Paulo (PUC/SP); Mestre em Direito Processual Civil pela Universidade Federal do Espírito Santo (UFES); Coordenador dos Grupos de Pesquisa "Desafios do Processo" e "Medicina Defensiva" (PPGDIR/UFES); Advogado. Vitória, ES, BR. E-mail: <gilberto.silvestre@ufes.br>.http://orcid.org/0000-0003-3604-7348

*Acadêmico de Direito da Universidade Federal do Espírito Santo (UFES); Pesquisador da Fundação de Amparo à Pesquisa e Inovação do Espírito Santo (FAPES) no Programa Institucional de Iniciação Científica (UFES/PIIC/FAPES) e dos Grupos de Pesquisa "Desafios do Processo" e "Medicina Defensiva”. Vitória, ES, BR. E-mail: <felipe.tres@hotmail.com>. https://orcid.org/0000-0001-99767284
} 
O dever da parte sucumbente de indenizar a parte vencedora pelos prejuízos com o processo. Ou, é possível ganhar sem perder?

\section{RESUMO}

Objetivo: Trata-se de pesquisa destinada a analisar a controvérsia existente no sistema judicial brasileiro quanto à reparação de perdas e danos sofridas pela parte que vence uma ação judicial, em decorrência da contratação de profissional da advocacia para atuar em juízo em seu favor. A pesquisa traçou como problema a ser respondido se é possível conceber, de lege lata, um sistema de responsabilidade civil para que a parte sucumbente em uma ação judicial indenize a parte vencedora pelos prejuízos decorrentes dessa ação.

Metodologia: Adotando um método qualiquantitativo, a pesquisa verificou os julgados do Superior Tribunal de Justiça atinentes à possibilidade da restituição dos honorários contratuais ao vencedor da demanda, bem como os fundamentos utilizados para tais decisões.

Resultados: Constatou que o entendimento majoritário nas Turmas do Superior Tribunal de Justiça acerca da questão não se alinha às interpretações dadas aos art. 389, 395 e 404 do Código Civil, que incluem os honorários contratuais como parcela das perdas e danos passíveis de ressarcimento em favor da vítima do ilícito.

Contribuições: A metodologia de revisão bibliográfica revelou que apesar de existir suficiente substrato normativo e teórico reconhecendo a possibilidade, os tribunais não a aplicam de forma pacífica. A pesquisa, então, elabora uma tese propositiva e inspiradora que fundamenta o dever da parte sucumbente de indenizar a parte vencedora pelos prejuízos que esta teve com a contratação de um advogado para estar em juízo.

Palavras-chave: Honorários contratuais. Sucumbência. Abuso de direito de ação. Perdas e danos.

\section{ABSTRACT}

Objective: This is a research aimed at analyzing the controversy existing in the Brazilian judicial system regarding the reparation of losses and damages suffered by the party that wins a lawsuit, due to the hiring of a legal professional to act in court in its favor. The research outlined as a problem to be answered whether it is possible to conceive, of lege lata, a civil liability system so that the party succumbing to a lawsuit indemnifies the winning party for the losses resulting from that action.

Methodology: Adopting a qualitative and quantitative method, the research verified the judgments of the Superior Court of Justice regarding the possibility of restoring 
contractual fees to the winner of the claim, as well as the grounds used for such decisions.

Results: It found that the majority understanding in the Superior Court of Justice's Sections on the issue does not align with the interpretations given to articles 389, 395 and 404 of the Civil Code, which include contractual fees as part of the losses and damages subject to reimbursement in favor the victim of the offense.

Contributions: The literature review methodology revealed that although there is sufficient normative and theoretical substrate recognizing the possibility, the courts do not apply it in a peaceful manner. The research, then, elaborates a propositional and inspiring thesis that justifies the duty of the succumbing party to indemnify the winning party for the losses that it had with the hiring of a lawyer to be in court.

Keywords: Contractual fees. Succumbence. Abuse of right of action. Losses and damages.

\section{RESUMEN}

Objetivo: Esta investigación tiene como objetivo analizar la controversia existente en el sistema judicial brasileño sobre la reparación de los daños y perjuicios sufridos por la parte que gana una demanda, debido a la contratación de un profesional del derecho para actuar en los tribunales a su favor. La investigación planteó como problema a responder si es posible concebir, de lege lata, un sistema de responsabilidad civil para que la parte que sucumbe a una demanda indemnice a la parte ganadora por las pérdidas resultantes de esa acción.

Metodología: Adoptando un método cualitativo y cuantitativo, la investigación verificó las sentencias del Superior Tribunal de Justicia sobre la posibilidad de restituir los honorarios contractuales al adjudicatario del reclamo, así como los fundamentos utilizados para tales decisiones.

Resultados: Se constató que el entendimiento mayoritario en las clases de la Corte Superior de Justicia sobre el tema no se alinea con las interpretaciones dadas a los artículos 389, 395 y 404 del Código Civil, que incluyen los honorarios contractuales como parte de las pérdidas y daños sujetos a reembolso a favor de la víctima del hecho ilícito.

Contribuciones: La metodología de revisión de la literatura reveló que si bien existe suficiente sustrato normativo y teórico que reconoce la posibilidad, los tribunales no lo aplican de manera pacífica. La investigación, entonces, elabora una tesis proposicional e inspiradora que justifica el deber de la parte sucumbiente de indemnizar a la parte 
O dever da parte sucumbente de indenizar a parte vencedora pelos prejuízos com o processo. Ou, é possivel ganhar sem perder?

ganadora por las pérdidas que tuvo con la contratación de un abogado para estar en la corte.

Palabras clave: Honorarios del contrato. Sucumbencia. Abuso del derecho de acción. Pérdidas y daños.

\section{INTRODUÇÃO}

Trata-se de pesquisa cujo objeto é demonstrar a viabilidade de um sistema de responsabilidade civil decorrente da sucumbência em uma ação judicial cível, com o objetivo reflexo de apresentar uma proposta inspiradora para mitigar os excessos que a ampla interpretação do alcance do acesso à justiça proporciona, o que prejudica a adequada e eficaz prestação da tutela judicial no Brasil.

A pesquisa se iniciou a partir da constatação de uma problemática que existe na atual sistemática processual brasileira - consequência, por certo, da compreensão quase que absoluta do acesso à justiça -, qual seja: geralmente, quem vence uma ação ("processo") ganha perdendo, pois, para responder à ação, a parte vencedora tem custos e prejuízos que não são cobertos, por exemplo, pelos consectários da sucumbência.

Um típico exemplo são os honorários contratuais pagos ao advogado para atuar no processo, que são um plus aos honorários sucumbenciais que este advogado recebe, e não a parte vencedora.

Daí advém o problema que esta pesquisa intentou resolver: é possivel conceber, de lege lata, um sistema de responsabilidade civil para que a parte sucumbente em uma ação judicial indenize a parte vencedora pelos prejuizos decorrentes dessa ação?

A hipótese foi construída com base na ideia de que a norma jurídica deve possuir como fim a tutela adequada dos direitos daquele que sofreu algum tipo de dano. $\mathrm{Ou}$ seja, aquele que provocou o Judiciário com uma demanda infundada ou o sujeito que ofereceu resistência infundada acerca da pretensão, deve ser responsabilizado por tal conduta. Por isso, a escolha do tema objeto dessa pesquisa está intimamente associada à relevância social da matéria e à sua relação com a política judiciária de melhor prestação jurisdicional e de acesso à justiça não abusivo.

Uma das maneiras de amenizar os danos da parte vencedora quanto aos danos a ela causados em decorrência da propositura da ação, é responsabilizar o sucumbido que reconhecidamente cometeu um ato ilícito - pelos honorários advocatícios da parte contrária. Esses valores integrarão as perdas e danos suportados pela parte vencedora, já que esse prejuízo só existiu em razão do cometimento do ilícito de outrem.

Ainda quanto à hipótese, uma análise preliminar dos arts. 389, 395 e 404 do Código Civil permitiu sustentar que o sucumbente deve arcar com a verba honorária extraprocessual da parte vitoriosa, ainda que no âmbito dos Juizados Especiais ou sob 
amparo da Assistência Judiciária Gratuita, já que aquela parte vencedora não pode suportar prejuízos por conta do processo que se viu obrigada a responder ou que foi indevidamente instaurado contra ela.

Portanto, uma vez distinguidas as verbas honorárias sucumbenciais e contratuais, é plenamente possível condenar o sucumbido ao pagamento de ambas, tendo em vista a diferença de suas naturezas jurídicas e observando a cláusula geral de abuso de direito do art. 187, combinada com a previsão dos art. 927 e 944, todos do Código Civil (que cuidam dos casos de responsabilidade extracontratual).

A pesquisa adotou a metodologia de revisão da literatura jurídica sobre os honorários advocatícios, concluindo pela necessidade de aplicação precisa da sucumbência e da restitutio in integrum. Nesse sentido, utilizou-se de uma abordagem de caráter qualiquantitativo da revisão da literatura jurídica e de julgados do Superior Tribunal de Justiça, no intuito de aprofundar os conceitos e teorias de direito material e processual, no que concerne especificamente a essa matéria. $\mathrm{O}$ método utilizado foi o dedutivo, buscando estabelecer referências gerais, para referências singulares, para a elaboração de uma conclusão de cunho genérico.

A pesquisa teve que se valer de revisão bibliográfica nos típicos manuais de processo civil, onde o tema é tema é melhor desenvolvido. Este, inclusive, foi um dos motivos que estimulou a pesquisa, objetivando dar ao assunto um tratamento mais científico e menos forense-opinativo.

As investigações tiveram por objetivos demonstrar a viabilidade da tese construída na hipótese a partir dos fundamentos normativos atualmente existentes no ordenamento jurídico brasileiro, bem como identificar prejuízos que decorrem da ação judicial e que devem ser indenizados pela parte sucumbida. Com isso, pretende-se mitigar - ou criar limites, se preferir - o acesso à justiça e o direito de ação, demonstrando que seu exercício pode sim ser abusivo.

O corte metodológico traçado restringiu a análise da matéria às ações de natureza civil, para que se pudesse traçar uma tese específica que não fosse prejudicada pelas peculiaridades de outras ações, principalmente as de natureza sancionatória (penal e improbidade, e.g.).

Ainda quanto ao corte metodológico, a pesquisa não aprofunda os conceitos de sucumbência e honorários, optando por ter as noções e discussões sobre esses institutos como pressuposto à leitura e compreensão deste trabalho. Não houve uma discussão sobre os institutos dos honorários com nuances mais avançadas e nem se avançou nas inter-relações da sucumbência apresentadas no Código de Processo Civil. Explica-se. O aprofundamento dessas temáticas paralelas não são o objeto de investigação primária do trabalho. O conhecimento das nuances dessas temáticas deve ser prévio à leitura do artigo. Ou seja, a pesquisa pretendeu oferecer um aprofundamento sobre uma das várias 
O dever da parte sucumbente de indenizar a parte vencedora pelos prejuízos com o processo. Ou, é possivel ganhar sem perder?

questões que decorrem daquelas temáticas maiores (honorários e sucumbência, por exemplo). $\mathrm{O}$ aprofundamento e a discussão das questões tangenciais poderiam prejudicar o foco que se quer dar à matéria específica, qual seja, a parte que perdeu indenizar a que ganhou pelos honorários que esta pagou ao advogado contratado.

Ao final, verificou-se que, a despeito da existência de embasamento normativo para a aceitabilidade da tese proposta, a instância especial e uniformizadora da jurisprudência brasileira não a aplica de forma pacífica. Por isso, a pesquisa pretende oferecer aos operadores do Direito argumentos hermenêuticos para viabilizar uma proposta inspiradora de alteração da aplicação das normas, de modo a proporcionar a tutela adequada e integral daquele que vence a ação judicial.

\section{PAGAMENTO DE HONORÁRIOS CONTRATUAIS PELA PARTE SUCUMBENTE EM DECORRÊNCIA DO EXERCÍCIO ABUSIVO DO DIREITO DE PETIÇÃO}

Os honorários advocatícios processuais constituem a remuneração dos advogados por sua atuação em um processo judicial exercendo a capacidade postulatória em benefício da parte. Dividem-se, primordialmente, em honorários contratuais e sucumbenciais, tendo, ambas, papéis diversos na função de reembolso (PINHO; SALLES, 2012, p. 266 e segs.).

Para Tucci (2019), há duas categorias de honorários em um processo:

a) honorários contratuais: representam o quantum estabelecido entre cliente e advogado a partir do pleno exercício de suas autonomias contratuais e;

b) honorários sucumbenciais: decorrem diretamente de condenação e arbitramento por decisão judicial do sucumbente para pagar honorários ao advogado da parte contrária tida como vencedora.

No mesmo sentido, mas com outra nomenclatura, Redondo e Müller (2015, p. 70) assim classificam os honorários, criticando a designação "honorários de sucumbência":

os honorários advocatícios podem ser de duas ordens (art. 22 da Lei 8.906/1994): convencionais (estipulados, no plano do direito material, entre o cliente e o seu advogado) e jurisdicionais (fixados, pelo juiz, em demanda judicial), estes últimos usualmente denominados "honorários de sucumbência" (terminologia equívoca, uma vez que a fixação de verba honorária nem sempre ocorre em razão de sucumbência, isto é, de derrota no fim da demanda, podendo os honorários ser fixados para remunerar o trabalho do advogado já no início da demanda, v.g., honorários para as fases de liquidação ou execução). 
O art. 85 do Código de Processo Civil tratou de garantir que o vencido deverá pagar honorários ao causídico da parte vitoriosa. Portanto, tal dispêndio será imposto ao sucumbente em proveito do representante judicial da parte contrária, como forma de se estabelecer um ônus àquele que deu ensejo à demanda sem o substrato jurídico suficiente para tal, ou mesmo para aquele que resistiu à pretensão de forma temerária.

Porém, o $\$ 14$ do art. 85 do Código de Processo Civil tratou os honorários sucumbenciais como um direito autônomo do advogado do litigante vencedor, de natureza alimentar, não se tratando, portanto, de uma espécie de reembolso da parte pelo que gastou com o processo (THEODORO JÚNIOR, 2018, p. 318; PINTO, 2019).

Percebe-se que a parte vencedora, a qual teve de contratar um advogado - seja para instaurar uma demanda judicial, em razão da recusa de adimplemento da obrigação pela parte contrária, seja para se defender de uma demanda que, ao final, mostrou-se infundada (improcedente) - suportou um prejuízo em sua esfera patrimonial em razão da conduta processual ilegítima, desnecessária e inadequada da outra parte.

É aí que surge o questionamento: é possível condenar a parte sucumbente, em paralelo à condenação nos honorários sucumbenciais, a indenizar a parte vencedora pelo que esta dispendeu contratando um advogado (honorários advocatícios)?

Orlando Zanon Junior e Schulze (2015, p. 422-424) são contrários a esse entendimento e sustentam a inviabilidade de condenar o sucumbente a indenizar a parte vencedora nos valores dos honorários contratados com seu advogado. Segundo eles, a responsabilidade civil do sucumbente pelas despesas com honorários contratuais da outra parte é uma tese que não deve prevalecer

Devendo ser mantido o entendimento de que a parte perdedora somente pode ser sucumbente quanto a uma única parcela remuneratória em favor do advogado da parte adversa, na extensão de sua derrota, haja vista que, primeiro, não é viável a dupla condenação indenizatória, em favor do causídico e também adicionalmente da parte; e, segundo, de acordo com a configuração jurídica atual da sucumbência, a remuneração de procurador consubstancia um encargo negocial intransferivel a outrem (ZANON JUNIOR; SCHULZE, 2015, p. 422).

Entendem que a remuneração é do profissional e é única, e chamam àquela possibilidade de "indenização duplicada", de modo que

A parte derrotada não pode ser condenada a custear duplamente a indenização da verba honorária, sob pena de se estabelecer três hipóteses de nascimento da remuneração profissional por um mesmo serviço, uma contratual (originária) e outra indenizatória duplicada (sucumbencial), esta última dividida em uma parcela em favor do advogado e repetida também em favor da parte, em flagrante (ZANON JUNIOR; SCHULZE, 2015, p. 422). 
O dever da parte sucumbente de indenizar a parte vencedora pelos prejuízos com o processo. Ou, é possivel ganhar sem perder?

Outro ponto questionado por Zanon Junior e Schulze (2015, p. 423) é que essa indenização se fundaria sobre um valor que foi livremente fixado entre a parte ax adversa e o procurador escolhido, ou seja, "ao arbítrio de tabela de órgão profissional que não necessariamente reflete as variações e características do mercado."

Ocorre, porém, que essa pesquisa encontrou fundamentos jurídicos e hermenêuticos para sustentar uma posição contrária a essa.

Apesar de o Direito brasileiro garantir a cada indivíduo o exercício do direito de petição, por meio da ação ou da defesa, ele não pode ser exercido de forma desarrazoada (rectius: abusiva). Sendo assim, caso tal direito subjetivo seja exercido de modo temerário e, portanto, desviando-se da finalidade adequada da norma, o ato que, prima facie seria lícito, tornar-se-ia um ilícito (NERY JUNIOR, 2009, p. 391). E isso em razão da abusividade do exercício daquela potestade de petição.

Logo, é sim possível falar na possibilidade de um "abuso de direito de ação", que, sendo emulação (ilícito), deve ser combatido pelo Direito e pela política judiciária, pois do contrário haverá prejuízos ao sistema (SILVESTRE; LIMA NETO, 2020). Nesse sentido, também, Rodrigues (2011, p. 850): "O sistema processual confere aos seus usuários um plexo de situações equivalentes a direitos subjetivos que devem ser exercidas dentro de limites. Ao ultrapassá-los, o sujeito incorre em abuso do sistema, fato que não merece acolhida."

O art. 187 do Código Civil estabelece: "Art. 187. Também comete ato ilícito o titular de um direito que, ao exercê-lo, excede manifestamente os limites impostos pelo seu fim econômico ou social, pela boa-fé ou pelos bons costumes." (BRASIL, 2002, online). Dessa forma, foi previsto o conceito jurídico indeterminado do abuso do direito, a qual abarca situações em que o direito concedido pelo ordenamento ao sujeito é exercido de forma contrária aos padrões, objetivos e limites do Direito.

Em tais situações, haverá, em verdade, o abuso do exercício do direito subjetivo ou potestativo e não do próprio direito em si, o qual seguirá sendo legítimo (RODOVALHO, 2012, p. 118). Logo, a parte ao exercer seu direito, pode vir a lesar outrem, ainda que não imagine estar saindo da linha imaginária que considera ser seu direito (PONTES DE MIRANDA, 1966, p. 67).

O exercício do direito por seus respectivos titulares deve se dar dentro do liame para o qual foram criados pelo ordenamento e, de tal modo, uma vez não respeitado o objetivo de sua criação, o sujeito poderá incorrer no denominado abuso de direito. Nessa hipótese, formalmente o ato seria legal, contudo, a materialização do exercício desse mesmo direito se daria de forma anormal.

Diante disso, o sujeito que incorresse em abuso de direito estaria, por conseguinte, incorrendo no ato ilícito previsto pelo art. 187 do Código Civil e, por isso teria o dever de indenizar a parte contrária, de acordo com o que prescreve o caput do 
art. 927 do Código Civil: "Art. 927. Aquele que, por ato ilícito (arts. 186 e 187), causar dano a outrem, fica obrigado a repará-lo. [...]." (BRASIL, 2002, online). Assim, aquele que abusar de um direito será responsabilizado pelo ato sem necessidade de comprovação de culpa, tampouco do intuito de prejudicar.

Por consequência lógica, aquele que exerceu um direito, prima facie legítimo, em desacordo com a boa-fé objetiva e a função social, econômica e os bons costumes, estará suscetível a incorrer em abuso de direito e, portanto, em um ato ilícito. Constatado o ilícito, surgiria a obrigação de indenizar a vítima do abuso na medida em que o dano foi experimentado por ela, com vistas ao art. 944 do Código Civil.

No entendimento de Carpena (2001, p. 383), para a constatação do abuso de direito "basta a inobservância dos limites axiológicos para caracterizá-lo (o abuso de direito), sem contemplação de sua extensão ou evidência.”

Assim sendo, constatada a contrariedade entre a ação ou omissão do sujeito e o elemento axiológico da norma, estar-se-á caracterizado o abuso do direito, podendo este ser suscitado pela parte interessada, pelo Ministério Público ou mesmo ser reconhecido ex officio pelo magistrado. Ademais, a averiguação do abuso de direito se dará objetivamente ao verificar-se a eventual contradição entre a conduta e os valores do sistema (LOPEZ, 2009, p. 557).

O ordenamento garante aos indivíduos o direito de ação e de defesa, os quais poderão ser exercidos até a margem do neminem lædere.

Dentre as garantias dos cidadãos, tem-se o direito de ação e de defesa. Ocorre que esses, assim como qualquer outra espécie de direito, não podem ser exercidos de forma diversa da qual foi criado pelo ordenamento jurídico. Desse modo, os litigantes, ao exercerem atos processuais estarão suscetíveis a incorrerem na cláusula geral do abuso de direito do art. 187 do Código Civil.

O abuso do direito de ação - que engloba o abuso do direito de defesa - não busca impedir que algum cidadão acesse o Judiciário, mas sim mitigar a prática de atos processuais em desconformidade com o próprio exercício da ação e com os fins a que o processo se destina.

Por isso, a ideia de abuso do direito da ação ou abuso do direito de petição costuma ser associada à litigância de má-fé, prevista no Código de Processo Civil nos arts. 79 a 81, os quais visam proibir que o improbus litigator faça prevalecer, frente à parte ex adversa, um falso direito (LIMA, 1978, p. 43).

$\mathrm{O}$ art. 80 do Código de Processo Civil prevê, in verbis:

Art. 80. Considera-se litigante de má-fé aquele que:

I - deduzir pretensão ou defesa contra texto expresso de lei ou fato incontroverso;

II - alterar a verdade dos fatos;

III - usar do processo para conseguir objetivo ilegal; 
O dever da parte sucumbente de indenizar a parte vencedora pelos prejuízos com o processo. Ou, é possivel ganhar sem perder?

IV - opuser resistência injustificada ao andamento do processo;

$\mathrm{V}$ - proceder de modo temerário em qualquer incidente ou ato do processo;

VI - provocar incidente manifestamente infundado;

VII - interpuser recurso com intuito manifestamente protelatório (BRASIL, 2015, online).

Denota-se, portanto, o sujeito que atuar no processo "de má-fé, sob a forma de dolo, fraude, simulação, emulação, capricho, temeridade, violência ou mentira” estará litigando de má-fé (CASTRO FILHO, 1940, p. 141). Agindo dessa forma, o sujeito também incorrerá em abuso do direito processual, logo será caracterizado o ato ilícito passível de indenização.

Sendo assim, o sujeito que exerceu seu direito de ação ou defesa em desacordo com seu fim social ou econômico, com a boa-fé objetiva, com os bons costumes, bem como o improbus litigator incorrerão na prática de ilícitos indenizáveis.

Dito isso, quando a parte acessa o Judiciário com uma demanda manifestamente infundada, na qual notoriamente não possui o direito material pleiteado ou quando o polo passivo resiste a pretensão em que, manifestamente a parte contrária é detentora do direito material, estará configurado o abuso que ensejará indenização.

Havendo acolhimento da demanda, há um pressuposto de que houve um ilícito original, contratual ou extracontratual, reconhecido judicialmente, e cuja resistência obrigou o credor a ingressar em juízo, gerando assim a responsabilidade à indenização integral. Já na outra perspectiva, se a demanda não é acolhida, não há de se falar em reconhecimento de um ato ilícito original, mas não deixará de haver ao menos ato abusivo, visto que o litigante pleiteou o que não lhe era devido.

Uma vez percebido que o decréscimo patrimonial do vencedor para a contratação de seu advogado, considera-se este um dano direto e imediato decorrente da conduta temerária de seu adversário processual que abusou do seu direito de petição, já que não fosse essa a atitude do sucumbente, a vítima não teria experimentado tal prejuízo.

Logo, para que exista responsabilidade civil, é fundamental que exista um dano causado por um indivíduo que cause prejuízo a esfera jurídica de outrem. Será possível interligar o a conduta, o dano e o prejuízo por meio do nexo de causalidade, o qual também estabelecerá o limite da obrigação de indenizar.

Ademais, segundo Cavalieri Filho (2018, p. 259), o ordenamento jurídico brasileiro, com relação ao nexo de causalidade, adotou a chamada teoria da causalidade adequada, em que será indagado se uma determinada condição concorreu concretamente para o evento, além de se apurar em abstrato se essa era adequada para produzir esse efeito. A circunstância que foi decisiva para o acontecimento do resultado será aquela abarcada por essa teoria. Isso é, ainda que não se entenda que a conduta daquele que abusou de seu direito não causou dano direto e imediato à parte contrária, 
é possível, por meio da teoria da causalidade adequada associar a conduta do que cometeu ato ilícito do dano sofrido pela vítima.

Destarte, é evidente que a conduta daquele que abusou de seu direito, incorrendo em um ato ilícito possui nexo de causalidade com o dano patrimonial sofrido pelo vencedor processual que teve de pagar seu advogado e, portanto, de acordo com o os arts. 187, 927 e 944 do Código Civil, deverá ser ressarcido por esse dano objetivamente, sem comprovação de culpa da parte contrária. E essa responsabilidade civil pelo abuso do direito de processo, inclusive, será objetiva, pois a responsabilidade por ato emulativo, no Direito brasileiro, tem essa natureza (CARVALHO, 2008, p. 97).

Além disso, não é estranha ao Código Civil esse tipo de indenização, conforme se percebe nos arts. 389, 395 e 404, in verbis:

Art. 389. Não cumprida a obrigação, responde o devedor por perdas e danos, mais juros e atualização monetária segundo índices oficiais regularmente estabelecidos, e honorários de advogado.

Art. 395. Responde o devedor pelos prejuízos a que sua mora der causa, mais juros, atualização dos valores monetários segundo índices oficiais regularmente estabelecidos, e honorários de advogado.

Art. 404. As perdas e danos, nas obrigações de pagamento em dinheiro, serão pagas com atualização monetária segundo índices oficiais regularmente estabelecidos, abrangendo juros, custas e honorários de advogado, sem prejuízo da pena convencional (BRASIL, 2002, online).

Percebe-se que o próprio Código Civil inclui os honorários advocatícios como parte integrante das perdas e danos. E é evidente que nesse caso está se referindo aos honorários contratuais, aqueles que representam a monta a ser paga pela parte em benefício do advogado que o auxiliou judicial ou extrajudicialmente. Esses honorários representarão a manifestação da autonomia privada do profissional e de seu cliente ao firmarem o contrato de prestação de serviços advocatícios.

Ressalta-se que não existem limites legais para a fixação desses valores, devendo apenas serem acordados de maneira razoável, de acordo com as orientações do Código de Ética e Disciplina da $\mathrm{OAB}$, que em seu art. 36 elenca critérios capazes de balizar o assentamento moderado dos honorários contratuais:

Art. 36. Os honorários profissionais devem ser fixados com moderação, atendidos os elementos seguintes:

I - a relevância, o vulto, a complexidade e a dificuldade das questões versadas;

II - o trabalho e o tempo necessários;

III - a possibilidade de ficar o advogado impedido de intervir em outros casos, ou de se desavir com outros clientes ou terceiros;

IV - o valor da causa, a condição econômica do cliente e o proveito para ele resultante do serviço profissional;

V - o caráter da intervenção, conforme se trate de serviço a cliente avulso, habitual ou permanente; 
O dever da parte sucumbente de indenizar a parte vencedora pelos prejuízos com o processo. Ou, é possivel ganhar sem perder?

VI - o lugar da prestação dos serviços, fora ou não do domicílio do advogado;

VII - a competência e o renome do profissional;

VIII - a praxe do foro sobre trabalhos análogos (OAB, 1995, online).

Os honorários advocatícios contratuais são, evidentemente, originados de uma obrigação de meio, uma vez que o patrono não pode garantir ao seu cliente qualquer tipo de resultado em eventuais demandas judiciais e não podem ser confundidos com os honorários sucumbenciais, decorrentes do próprio processo.

Dessa forma, aquele que não teve seu pedido reconhecido pelo juízo deverá suportar, dentre outras culminações, também com os honorários contratuais do advogado da parte contrária, uma vez constado o ato ilícito gerador do dever de indenizar. Portanto, além de arcar com o dissabor de não obter seus pleitos acolhidos pelo órgão julgador, terá de subsidiar o pagamento de custas e honorários advocatícios da parte ex adversa de cunho contratual e sucumbencial, ou seja, suportará o denominado ônus da sucumbência (ONÓFRIO, 1998, p. 75).

Ter de suportar os ônus da sucumbência está intrinsecamente ligado ao fato da parte se encontrar em situação de derrotada processualmente em maior ou menor medida, seja ao propor a demanda, seja exercendo seu direito de defesa.

A sucumbência pode se dar, em âmbito processual, de mais de uma forma:

a) quando o conteúdo da decisão difere do que foi pleiteado pela parte, tem-se a chamada sucumbência formal ou;

b) quando o sujeito é colocado em situação pior a que se tinha antes do processo ou deixa de obter tudo aquilo que poderia ter obtido em decorrência de decisão desfavorável a ele, fala-se em sucumbência material (NERY JUNIOR, 2004, p. 315-316).

Sobre o a sucumbência, escreve e Chiovenda (1998, p. 242):

O fundamento dessa condenação é o fato objetivo da derrota; e a justificação desse instituto está em que a atuação da lei não deve representar uma diminuição patrimonial para a parte a cujo favor se efetiva; por ser interesse do Estado que o emprego do processo não se resolva em prejuízo de quem tem razão, e por ser, de outro turno, interesse do comércio jurídico que os direitos tenham um valor tanto quanto possível nítido e constante.

A sucumbência deve impor ao perdedor da demanda que seja responsabilizado pelos custos da outra parte, em virtude da instauração da lide. De tal forma o Código de Processo Civil estabelece, em seu art. 85, a natureza alimentar dos honorários sucumbenciais, os quais serão pagos pelo perdedor da demanda diretamente ao advogado da parte vencedora, como forma de remunerar o advogado vitorioso processualmente (CORDOPATRI, 1991, p. 188). 
Sendo assim, mostra-se desarrazoado que aquele que no âmbito processual se encontra em situação de vantagem garantida pelo ordenamento jurídico tenha de, além de outros prejuízos de natureza extraprocessual, suportar também com os valores dos serviços advocatícios por ele contratados, porquanto a necessidade de tal contratação tenha surgido a partir da propositura de uma ação que se revela um verdadeiro ilícito da parte ex adversa.

Os arts. 389, 395 e 404 do Código Civil corroboram para o entendimento da importância de que a sucumbência cumpra com seu objetivo de reaver o patrimônio daquele que experimentou prejuízos, a título de perdas e danos. É evidente, por conseguinte, que tais formulações normativas tratam dos honorários contratuais a serem ressarcidos pelo sucumbente, uma vez que, caso o entendimento fosse contrário, a parte vencedora não seria integralmente ressarcida (STJ, REsp nº 1.027.797/MG, 3a Turma, Rel. Min. Nancy Andrighi, julgado em 17/02/2011). Nesse sentido, conforme Nogueira (2009, p. 602):

Pela sistemática do direito material que garante a ampla indenização, amparada no conhecido princípio da restitutio in integrum, mostra-se bastante razoável a interpretação no sentido de que os dispositivos do Código Civil visam, realmente, disciplinar a indenização dos honorários advocatícios extrajudiciais. O direito material, portanto, vai além das regras de direito processual, permitindo a recomposição de tudo aquilo que a parte despendeu para fazer valer seus interesses (em juízo ou fora dele), inclusive as verbas contratuais comprometidas aos advogados que atuam em sua representação.

Ademais, pelo caput do art. 944 do Código Civil o ordenamento jurídico brasileiro instituiu que a indenização deve ser medida pela extensão dos prejuízos sofridos pela parte lesada, consubstanciando, de tal forma, a regolæ juris da restitutio in integrum, pela qual o lesado deverá ser ressarcido de todos os decréscimos patrimoniais que experimentou em decorrência do ato ilícito de outrem.

Ao imputar encargos indevidos ao sujeito que teve suas postulações acatadas pelo juízo, sequer poderia se falar que este fora vitorioso, uma vez que teve de arcar com gastos para vencer e, por isso sua reparação não se deu de forma integral. Dessa forma, aquele que tem razão deve ser visto como se estivera em situação idêntica à que estaria, caso a outra parte não lhe houvesse causado o dano (DINAMARCO, 2005, p. 647).

Nesse sentido entende Cahali (1997, p. 50), para quem "se as despesas tivessem de ser pagas pelo vencedor, a recomposição do direito reconhecido pela sentença seria, sem qualquer justificação, apenas parcial.”

É fundamental que o ordenamento jurídico garanta que a restituição se dê na medida do evento danoso, com fins de elevar o lesado ao patamar anterior à ocorrência do ato ilícito. Tal fato só será passível de ocorrência, caso a sucumbência se der de modo 
O dever da parte sucumbente de indenizar a parte vencedora pelos prejuízos com o processo. Ou, é possivel ganhar sem perder?

com que cumpram com seus propósitos e, interligada com a responsabilidade civil, alcance a reparação integral do dano (SANSEVERINO, 2010, p. 19).

Esse é o entendimento de Scavone Júnior (2007, p. 172 e ss.):

Sendo assim, os honorários mencionados pelos arts. 389, 395 e 404 do Código Civil, ressarcitórios, evidentemente não são aqueles decorrentes do Estatuto da Advocacia, ou seja, os honorários de sucumbência; de outro lado, são pagos diretamente pelo credor ao advogado e constituem em prejuízo (dano emergente) decorrente da mora e do inadimplemento. [...]. Assim os honorários atribuídos a título de sucumbência não se confundem como os honorários ressarcitórios, convencionais ou arbitrados. Os honorários ressarcitórios, convencionais ou arbitrados, representam dispêndio do credor e, por essa razão, perdas e danos decorrentes do inadimplemento das obrigações, notadamente em razão da necessidade de contratação de advogado para efetivar o direito de receber o objeto da prestação da relação jurídica obrigacional. Rompe-se, em razão do ordenamento jurídico, o entendimento corrente, porém equivocado, que decorria do direito anterior, segundo o qual apenas haveria lugar para a condenação do devedor nos honorários de sucumbência. Não é crível, ante o princípio da restituição integral, que os honorários pagos pelo credor sejam por ele suportados sem qualquer ressarcimento pelo devedor, que a eles deu causa.

Parece evidente, com a previsão dos art. 389, 395 e 404 do Código Civil, que os valores despendidos a título de honorários advocatícios integrariam as perdas e danos, pois o legislador objetivou que a verba honorária contratual despendida pela vítima de um ilícito pudesse ser reclamada no próprio processo que deu azo à lide.

$O$ fato de o vencedor processual estar facultado a demandar que sejam ressarcidos os valores desembolsados por ele com honorários contratuais de advogado, não possui relação com a condenação do perdedor em honorários sucumbenciais em favor do advogado da parte contrária, uma vez que as duas espécies de verbas possuem origem e destinatário diversos. Enquanto os honorários sucumbenciais arbitrados pelo juízo possuem natureza remuneratória e alimentar - serão decorrentes da própria derrota processual e terão como destinatário final o causídico do vencido -, a condenação do sucumbente ao pagamento dos honorários advocatícios contratuais decorrerá do fato de tais verbas representarem parte integrante das perdas e danos causadas em virtude de seu ilícito e, além disso, o beneficiário de tais valores será diretamente o próprio vencedor, com natureza evidente de indenização.

Em assim sendo, ao prever que o sucumbido deverá restituir as verbas despendidas pelo vencedor com advogado a título de perdas e danos, não poder-se-ia caracterizar, de tal modo, um bis in idem, pois a condenação ao pagamento de honorários sucumbenciais advém do próprio escopo do processo em curso, não possuindo relação direta com a previsão do Código Civil, o qual prevê que o pagamento 
de honorários advocatícios da parte vencedora pelo sucumbente constitui, em verdade, parcela das perdas e danos por aquela suportada.

Assim, o sucumbente não estaria sendo punido duas vezes pelo mesmo fato gerador, ao arcar com os honorários contratuais da parte contrária, e sim indenizando as perdas e danos da parte ex adversa em sua integralidade, além das despesas de natureza processual que direta ou indiretamente instaurou, uma vez que ao abusar de seu direito de ação ou de defesa incorreu em um ato ilícito passível de indenização.

A sucumbência não se mostra suficiente, per se, para disciplinar a responsabilidade dos encargos envolvidos no desenvolvimento do processo (CAHALI, 1997, p. 56). Portanto, deve ser vista como um meio necessário para que se atinja a reparação integral do dano experimentado pela vítima de um abuso de petição (processual).

Logo, deve-se atribuir ao vencido processual os encargos advindos do processo, incluindo os honorários advocatícios contratuais despendidos pela parte. Nesse sentido, Theodoro Júnior (2015, p. 296) entende que "atribui-se à parte vencida na causa a responsabilidade por todos os gastos do processo, assentando-se tal consequência na ideia fundamental de que o processo não deve redundar em prejuízo à parte que tenha razão."

Não se justifica a existência de uma indenização íntegra sem que o prejudicado possa ser ressarcido do montante que desembolsou para contratar seu advogado, para obter pela via judicial o adimplemento forçado da obrigação ou para refutar a pretensão que se revelou infundada, já que, por constituírem direito autônomo do advogado da parte vencedora, os honorários sucumbenciais não importam em lesão ao patrimônio da parte vencedora, mas os contratuais sim e, por tal motivo, são estes os mencionados nos arts. 389, 395 e 404 do Código Civil (STJ, REsp. n. 1.134.725/MG, 3a Turma, Rel. Min. Nancy Andrighi, julgado em 14/06/2011).

Não se pode imputar ao vencedor de uma disputa judicial qualquer tipo de prejuízo, por causa da própria finalidade que se atribui ao processo civil, qual seja a de conceber àquele que tem razão uma situação no mundo fático melhor que a que se encontrava anteriormente ao ajuizamento da ação (DINAMARCO, 2017, p. 198).

Nesse mesmo sentido entendeu a Terceira Turma do Superior Tribunal de Justiça em 2019, ao julgar o Recurso Especial no. 1.703.356/MG (STJ, REsp. nº. 1.703.356/MG, 3a Turma, Rel. Min. Nancy Andrighi, julgado em 22/10/2019). A Terceira Turma interpretou que o vencedor não deveria sofrer prejuízos em virtude do processo, caso contrário estaria sendo retirada do processo sua função de conferir aos litigantes uma tutela jurisdicional justa.

Portanto, é impossível que a necessidade de que o perdedor suporte os honorários advocatícios contratuais do vencedor seja dissociada das normas que regem a 
O dever da parte sucumbente de indenizar a parte vencedora pelos prejuízos com o processo. Ou, é possivel ganhar sem perder?

distribuição entre as partes dos encargos e despesas processuais. A partir dessa análise sistemática é possível estabelecer que toda ação indevidamente posta, ou mesmo a resistência injustamente oposta, deve significar um típico ato ilícito (art. 187 do Código Civil), orientado pela responsabilidade civil objetiva (parágrafo único do art. 927 do Código Civil), de forma a obrigar a parte que deu ensejo à demanda a ressarcir não só os honorários advocatícios processuais de natureza sucumbencial previsto no art. 85 do Código de Processo Civil, mas também os de viés extrajudicial, consubstanciados nos arts. 389, 395 e 404 do Código Civil.

$\mathrm{Na}$ Lei $\mathrm{n}^{\circ} .9 .099 / 1995$, os arts. 54 e 55 preveem algumas facilidades para as partes com o objetivo de garantir o acesso à justiça. Assim é que, no âmbito dos Juizados Especiais Cíveis a propositura de ações no primeiro grau independe do pagamento de custas, taxas ou outras despesas. Quanto à sentença de primeiro grau, esta não condenará o vencido em custas e honorários de advogado.

Percebe-se que o vencido experimenta, nesse âmbito de exercício da jurisdição, uma flexibilização da sucumbência, já que ele, ao menos em primeiro grau, não estará encarregado de pagar custas e honorários sucumbenciais ao vencedor.

Além disso, o art. 9० da Lei dos Juizados Especiais dispõe que será facultado aos litigantes a assistência de advogado para causas no valor de até 20 salários mínimos, sendo a presença do profissional obrigatória apenas nas causas com valor superior àquele.

Entretanto, apesar de isentar as partes da contratação de um causídico e eximilas em primeiro grau do pagamento de honorários sucumbenciais ao advogado do vencedor, os honorários contratuais despendidos por aquele que suportou um ato ilícito ainda seriam devidos. E assim o é uma vez que a verba honorária contratual não decorre do processo que tramita no Juizado e, de tal modo, não está abrangida pelo art. 55 da Lei no. 9.099/1995.

Outrossim, a lei faculta ao litigante a contratação de advogado, pois dá ao particular a capacidade postulatória para ações cujo valor da causa seja até 20 salários mínimos. Portanto, se a vítima de um ilícito entende por necessária a contratação de um profissional da advocacia, poderá se valer de tais serviços, justamente pelo fato de o legislador ter dado a ele o poder de escolha e, dessa forma, deixado a cargo da parte entender se precisa ou não de um assistente.

Por ser uma faculdade conferida pelo ordenamento, o fato de o sujeito optar pela contratação de profissional especializado não seria capaz de gerar alguma espécie de ilícito. Dessa forma entendeu a Segunda Seção do Superior Tribunal de Justiça no julgamento dos Embargos de Divergência no Recurso Especial nº 1.155.527/MG (STJ, EREsp nº. 1.155.527/MG, Segunda Seção, Rel. Min. Sidinei Beneti, julgado em 13/06/2012). 
O exercício do direito de ação tem como função precípua garantir que a parte possa demandar ao juízo de acordo com seu interesse, sendo a figura do advogado imprescindível para o pleno exercício dessa faculdade.

Posto isso, caso o sujeito precise de um profissional apto a defender seus interesses e pleitear a tutela de seus direitos frente à parte contrária, não poderá se escusar de suportar a remuneração profissional. Assim sendo, nos casos de demandas discutidas no âmbito dos Juizados Especiais Cíveis, os honorários contratuais pagos pelo vencedor também ficariam a cargo do vencido, já que eles, assim como na Justiça Comum, integram as perdas e danos da vítima do ilícito.

Dentre os instrumentos de ampliação do acesso à justiça, o Direito brasileiro admite a possibilidade de o sujeito requerer o reconhecimento de sua hipossuficiência em juízo, a fim de que seja beneficiário da gratuidade de justiça (MAIA, 2010). Se concedido esse benefício ao litigante, este estará eximido de antecipar os encargos que decorrem do processo.

Porém, o $§ 2^{\circ}$ do art. 98 do Código de Processo Civil prescreve que, caso seja vencido no processo, o litigante hipossuficiente terá de arcar com os honorários sucumbenciais

A isenção de pagamento que beneficia o hipossuficiente é quanto às custas processuais, ou seja, as verbas que são devidas ao Estado para a propositura da ação. Elas não isentam o sucumbente hipossuficiente de pagar os consectários da sucumbência devidas à outra parte e ao seu advogado.

Logo, reconhecendo que a hipossuficiência é uma situação que produz efeitos entre parte hipossuficiente e Estado-Judiciário, não há prescrição legal que afaste que um hipossuficiente sucumbente tenha que indenizar os honorários contratuais despendidos pelo vencedor. A gratuidade é do acesso à justiça, e não da lide.

Essa imputação possivelmente teria outro efeito positivo, no sentido de evitar postulações e resistências temerárias, contribuindo para a não banalização do acesso à justiça, garantindo ao sistema judicial maior eficácia na tutela adequada (RIBEIRO, 2015). Nesse sentido, Cerqueira (2010, p. 242) destaca que a massificação do acesso à justiça (ou "ondas de acesso à justiça") prejudica o funcionamento das instituições judiciárias: "as chamadas ondas de acesso à justiça, [...], deságuam numa contradição: permitem cada dia mais o acesso aos tribunais, estes são transformados em pesadas estruturas, incapazes de resolver os conflitos de forma célere, adequada e efetiva". Por outro lado, Trigueiro e Borges (2019, p. 314 e segs.) apresentam dados baseados em análise econômica da litigância em que concluem que a condenação a pagamento de honorários se apresenta como mecanismo de desestímulo à litigância frívola e aos recursos meramente protelatórios. Logo, torna a litigância mais eficiente. 
O dever da parte sucumbente de indenizar a parte vencedora pelos prejuízos com o processo. Ou, é possivel ganhar sem perder?

\section{CRITÉRIOS PARA FIXAÇÃO DOS HONORÁRIOS CONTRATUAIS}

É fundamental estabelecer um critério objetivo para a fixação dos honorários advocatícios contratuais a serem pagos pelo sucumbente ao vencedor da demanda, uma vez que, a despeito de possuir esse direito, o vitorioso não pode experimentar um enriquecimento sem causa em razão da indenização.

Sendo assim, com vistas à objetividade, é possível estabelecer a Tabela de Honorários da Ordem dos Advogados do Brasil como paradigma de quantificação dos honorários advocatícios contratuais devidos ao vencedor (RIBEIRO, 2015). De tal modo, o magistrado poderia adequar o que foi pleiteado pelo vencedor com um padrão previamente posto. Esse foi o entendimento da Terceira Turma do Superior Tribunal de Justiça ao julgar o Recurso Especial no. 1.134.725/MG (STJ, REsp. nº. 1.134.725/MG, 3a Turma, Rel. Min. Nancy Andrighi, julgado em 14/06/2011), em que a Tabela da $\mathrm{OAB}$ foi utilizada como parâmetro para fixação dos honorários contratuais.

De maneira subsidiária, o juízo poderia aplicar a média que o mercado tem despendido para aquela espécie de serviço advocatício contratado.

Além disso, em caso de sucumbência parcial da parte, o magistrado será responsável por quantificar em que medida o sujeito foi perdedor, para-valorar o que lhe seria devido a título de perdas e danos pelos valores que suportou com os serviços do advogado.

Corroborando com essa ideia, Nogueira (2009, p. 602) assim entende:

Não há como temer o excesso na cobrança dessa verba, na hipótese de
comprovado abuso, poderá o juiz arbitrar o valor que entender devido (art.
946, CC), valendo-se de auxilio pericial, na forma do art. 475-A do CPC, ou
mesmo da Tabela de Honorários Advocatícios divulgada pela Ordem dos
Advogados do Brasil da Seccional correspondente. De igual forma, na
desproporção entre o valor dos honorários de advogado e o próprio montante
requerido a título de prejuízo principal, nada obsta a aplicação analógica do
parágrafo único do art. 944 do Código Civil, que admite redução equitativa
da indenização.

Não deve causar receios a referida responsabilidade civil, pois há métodos objetivos salutares que possibilitam a fixação do quantum de maneira segura.

É verdade, porém, que o serviço advocatício pode ter sido contratado por valores superiores ao da média do mercado ou da Tabela da OAB. E isso é um problema, pois não haverá a plena restitutio in integrum. Mas essa é uma medida que se destina a evitar uma possível torpeza ou simulação da parte vencedora e de seu advogado. Ou seja, talvez os valores de mercado e da Tabela não ressarçam o prejuízo patrimonial da parte vencedora, mas pelo amenizam dentro de parâmetros justos, seguros e objetivos. 
E há, outrossim, a situação reversa: o valor dos honorários contratuais acertados entre cliente e advogado é inferior à média de mercado e à Tabela da $O A B$, mas a condenação do sucumbido ao ressarcimento considera os valores destes critérios objetivos.

Para essa hipótese a conclusão é melancólica, pois a investigação na literatura e nos documentos judiciais e as discussões no âmbito da pesquisa não revelaram instrumentos de controle. Porém, entende-se que isso não retira o mérito da tese e é possível planejar futuramente o controle do quantum indenizatório nessa situação hipotética.

Assim, é possível responsabilizar o sucumbente pelos honorários advocatícios contratuais do vencedor da demanda sem que haja locupletamento por parte daquele que venceu e sem extrapolar a razoabilidade na fixação dos valores.

\section{ANÁlISE QUALIQUANTITATIVA DE JULGADOS DO SUPERIOR TRIBUNAL DE JUSTIÇA}

Há decisões que não admitem a cobrança dos honorários advocatícios extrajudiciais pela parte vitoriosa, não aplicando a sistemática por força da expressa menção a honorários contida no bojo dos arts. 389, 395 e 404 do Código Civil, que tratam de indenização.

Até a entrada em vigência do Código de Processo Civil de 2015 havia maior controvérsia jurisprudencial acerca da possibilidade do reembolso dos honorários contratuais do vitorioso pelo sucumbente.

A ratio juris utilizada pelo Superior Tribunal de Justiça tem partido da ideia de que essa indenização não é possível já que os custos decorrentes da contratação de advogado para ajuizamento de ação, por si só, não constituem ilícito indenizável. Ademais, demonstram que os valores despendidos com honorários contratuais pelo vencedor não integram as perdas e danos, uma vez que tal contratação se deu no âmbito da autonomia privada da parte.

A essa conclusão se chegou a partir de uma investigação de julgados do STJ que versavam acerca da matéria objeto da pesquisa. A metodologia e critérios foram os seguintes:

Quadro 1 - Metodologia e critérios

\begin{tabular}{|l|l|}
\hline Sítio eletrônico de pesquisa & www.stj.jus.br (https://scon.stj.jus.br/SCON/) \\
\hline Data da busca & $20 / 02 / 2020$ \\
\hline Período temporal & $01 / 01 / 2003$ a 20/02/2020 \\
\hline Critérios de busca & 1 ["honorários contratuais pelo sucumbente"] \\
\hline
\end{tabular}


O dever da parte sucumbente de indenizar a parte vencedora pelos prejuízos com o processo. Ou, é possível ganhar sem perder?

\begin{tabular}{|l|l|}
\hline & 2)[“honorários contratuais do vencedor"] \\
\hline Método & Qualiquantitativo \\
\hline Documentos selecionados & Acórdãos do STJ \\
\hline Total de documentos analisados & 51 \\
\hline
\end{tabular}

Fonte: elaboração própria.

Total de documentos selecionados por terem relação direta com o objeto da pesquisa: 29:

- STJ, REsp. n. 1.821.964/MS, Terceira Turma, Min. Ricardo Villas Bôas Cueva, julgado em 04/09/2019;

- STJ, REsp 1.815.348/SP, Quarta Turma, Min. Luis Felipe Salomão, julgado em 12/06/2019;

- STJ, AREsp 1.391.739/SP, Quarta Turma, Min. Antônio Carlos Ferreira, julgado em 07/06/2019;

- STJ, AREsp 1.243.310/SP, Quarta Turma, Min. Marco Buzzi, julgado em 04/06/2019;

- STJ, REsp 1.809.415/SP, Terceira Turma, Min. Marco Aurélio Belizze, julgado em 27/05/2019;

- STJ, REsp 1.694.570/MS, Terceira Turma, Min. Ricardo Villas Bôas Cueva, julgado em 26/10/2017;

- STJ, AgInt no AREsp 770.218/PR, Terceira Turma, Min. Paulo de Tarso Sanseverino, julgado em 02/05/2017;

- STJ, EREsp 1.507.864/RS, Corte Especial, Min. Laurita Vaz, julgado em 20/04/2016;

- STJ, AgRg no REsp 1.248.418/PR, Quarta Turma, Min. Raul Araujo, julgado em 07/03/2016;

- STJ, AgRg no REsp 1.539.014/SP, Terceira Turma, Min. Marco Aurélio Belizze, julgado em 03/09/2015;

- STJ, AgRg no REsp 1.481.534/SP, Quarta Turma, Min. Maria Isabel, julgado em 18/08/2015;

- STJ, AgRg no Resp 1.410.705/RS, Segunda Turma, Min. Humberto Martins, julgado em 10/02/2015;

- STJ, AgRg no AREsp 606.676/RS, Segunda Turma, Min. Humberto Martins, julgado em 10/02/2015;

- STJ, AgRg no AREsp 477.296/RS, Quarta Turma, Min. Antônio Carlos Ferreira, julgado em 16/12/2014; 
- STJ, AgRg no AREsp 430.399/RS, Quarta Turma, Min. Raul Araujo, julgado em 02/12/2014;

- STJ, AgRg no AREsp 516.277/SP, Quarta Turma, Min. Marco Buzzi, julgado em 26/08/2014;

- STJ, AgRg nos EDcl no REsp 1.412.965/RS, Terceira Turma, Min. Sidnei Beneti, julgado em 17/12/2013;

- STJ, EResp 1.155.527/MS, Segunda Seção, Min. Sidnei Beneti, julgado em 13/06/2012;

- STJ, Resp 1.027.797/MG, Terceira Turma, Min. Nancy Andrighi, julgado em 17/02/2011.

- STJ, AgInt no AREsp 1.294.687/SP, Quarta Turma, Min. Luis Felipe Salomão, julgado em 11/09/2018;

- AgInt no AREsp 914.889/RO, Terceira Turma, Min. Paulo de Tarso Sanseverino, jugado em 20/02/2018;

- AgInt no REsp 1.653.575/SP, Quarta Turma, Min. Maria Isabel Gallotti, julgado em 16/11/2017;

- AgRg no AREsp 746.234/RS, Segunda Turma, Min. Herman Benjamin, julgado em 27/10/2015;

- AgRg no REsp 1.229.482/SP, Terceira Turma, Min. Paulo de Tarso Sanseverino, julgado em 20/11/2012;

- AgRg no REsp 1.312.613, Terceira Turma, Min. Paulo de Tarso Sanseverino, julgado em 29/09/2014;

- AgRg no REsp 1.370.501/MS, Quarta Turma, Min. Raul Araújo, julgado em 25/08/2015;

- REsp 1.480.225/SP, Segunda Turma, Min. Og Fernandes, julgado em 25/08/2015;

- REsp 1.027.897/MG, Quarta Turma, Min. Aldir Passarinho Júnior, julgado em 16/10/2008; e

- REsp 1.274.629/SP, Terceira Turma, Min. Nancy Andrighi, julgado em 16/05/2013.

gráfico abaixo demonstra o percentual de julgados da amostragem que não reconheceu a possibilidade do reembolso: 
O dever da parte sucumbente de indenizar a parte vencedora pelos prejuízos com o processo. Ou, é possivel ganhar sem perder?

Gráfico 1 - Percentual de julgados da amostragem que não reconheceu a possibilidade do reembolso

- Não reconhece a possibilidade de reembolso

Reconheceu a possibilidade de reembolso

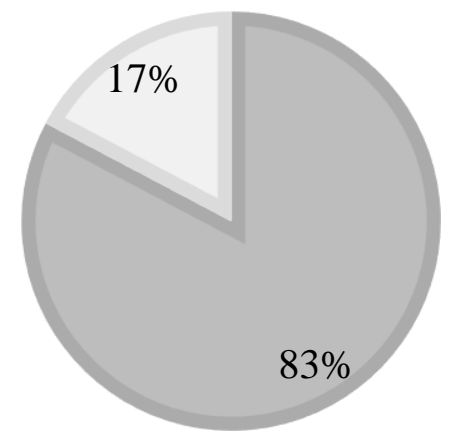

Fonte: dados da pesquisa.

Resumidamente, os fundamentos dos julgados que inadmitiram que o sucumbente reembolsasse os honorários contratuais despendidos pelo vencedor são os seguintes:

1) Cabe ao perdedor da ação arcar apenas com os honorários de advogado fixados pelo juízo em decorrência da sucumbência (art. 85 do Código de Processo Civil), uma vez que os honorários contratuais foram estabelecidos de forma alheia à vontade da parte contrária;

2) Precedentes estabelecidos de forma contrária a essa possibilidade e incidência da Súmula nº 83 do Tribunal;

3) Custos decorrentes da contratação de advogado para ajuizamento da ação, por si só, não constituem danos materiais indenizáveis; e

4) Honorários sucumbenciais suprem o comando dos arts. 389, 395 e 404 do Código Civil e são abrangidos pela expressão "honorários advocatícios".

A distribuição de fundamentos por julgado é a seguinte:

Quadro 2 - Distribuição de fundamentos por julgado

\begin{tabular}{|l|l|}
\hline \multicolumn{1}{|c|}{ FUNDAMENTO } & \multicolumn{1}{|c|}{ JULGADO } \\
\hline $\begin{array}{l}\text { Cabe ao perdedor da ação arcar apenas com os } \\
\text { honorários de advogado fixados pelo juízo em } \\
\text { decorrência da sucumbência (art. 85, CPC), uma vez } \\
\text { que os honorários contratuais foram estabelecidos de } \\
\text { forma alheia à vontade da parte contrária; }\end{array}$ & \\
\hline $\begin{array}{l}\text { Precedentes estabelecidos de forma contrária a essa } \\
\text { possibilidade. Incidência da Súmula 83, STJ; }\end{array}$ & $\bullet$ REsp 1.815.348/SP \\
& $\bullet$ AREsp 1.243.310/SP \\
\hline
\end{tabular}

84 - R. Opin. Jur., Fortaleza, ano 19, n. 30, p.63-90, jan./abr. 2021 


\begin{tabular}{|c|c|}
\hline $\begin{array}{l}\text { Precedentes estabelecidos de forma contrária a essa } \\
\text { possibilidade }\end{array}$ & $\begin{array}{ll}\text { - } & \text { REsp 1.821.964/MS } \\
\text { - } & \text { AREsp 1.391.739/SP } \\
\text { - } & \text { REsp 1.809.415/SP } \\
\text { - } & \text { REsp 1.694.570/MS } \\
\text { - } & \text { Ag Int no AREsp 770.218/PR } \\
\text { - } & \text { AgRg no REsp 1.248.418/PR } \\
\text { - } & \text { AgRg no REsp 1.481.534/SP } \\
\text { - } & \text { AgInt no AREsp 914.889/RO } \\
\text { - } & \text { AgInt no REsp 1.653.575/SP } \\
\text { - } & \text { AgRg no AREsp 746.234/RS } \\
\text { - } & \text { AgRg no REsp 1.370.501/MS } \\
\end{array}$ \\
\hline $\begin{array}{l}\text { Os custos decorrentes da contratação de advogado } \\
\text { para ajuizamento da ação, por si só, não constituem } \\
\text { danos materiais indenizáveis; }\end{array}$ & $\begin{array}{ll}\text { - } & \text { AgRg no REsp 1.539.014/SP } \\
\text { - } & \text { AgRg no AREsp 477.296/RS } \\
\text { - } & \text { AgRg no AREsp 430.399/RS } \\
\text { - } & \text { AgRg no AREsp 516.277/SP } \\
\text { - } & \text { AgRg no REsp 1.229.482/SP } \\
\text { - } & \text { REsp 1.480.225/SP } \\
\text { - } & \text { REsp 1.027.897/MG }\end{array}$ \\
\hline $\begin{array}{l}\text { Honorários sucumbenciais suprem o comando dos } \\
\text { arts. } 389,395 \text { e } 404 \text { do Código Civil e são abarcados } \\
\text { pela expressão "honorários advocatícios" presente } \\
\text { nesses. }\end{array}$ & - $\quad$ EResp 1.155.527/MS \\
\hline
\end{tabular}

Fonte: elaboração própria.

Já os julgados que entenderam pela possibilidade de reembolsar o vencedor pelos honorários advocatícios contratuais despendidos por ele tiveram, em linhas gerais os seguintes fundamentos:

1) Os honorários advocatícios contratuais integram as perdas e danos nos termos dos arts. 389, 395 e 404 do Código Civil, ou seja, o sintagma "honorários advocatícios" não tem a generalidade concebida pela outra vertente; e

2) Caberá ressarcimento dos honorários advocatícios contratuais decorrentes de contrato de prestação de serviços advocatícios extrajudiciais e, portanto, serviços privativos de bacharel em direito (consultoria, negociação efetiva de acordos com mútuos consentimentos, assessoria para adoção de medidas preparatórias etc.).

A distribuição de fundamentos por julgado se dá da seguinte forma:

Quadro 3 - Distribuição de fundamentos por julgado

\begin{tabular}{|l|c|}
\hline \multicolumn{1}{|c|}{ FUNDAMENTO } & JULGADO \\
\hline Os honorários advocatícios contratuais integram as & $\bullet$ AgRg no Resp 1.410.705/RS \\
perdas e danos nos termos dos arts. 389, 395 e 404 do & $\bullet$ AgRg no AREsp 606.676/RS \\
Código Civil & $\bullet \quad A g R g$ nos EDcl no REsp \\
\hline
\end{tabular}


O dever da parte sucumbente de indenizar a parte vencedora pelos prejuízos com o processo. Ou, é possivel ganhar sem perder?

\begin{tabular}{|l|l|}
\hline & $1.412 .965 / \mathrm{RS}$ \\
& $\bullet$ Resp 1.027.797/MG \\
\hline $\begin{array}{l}\text { Caberá ressarcimento dos honorários advocatícios } \\
\text { contratuais decorrentes de contrato de prestação de } \\
\text { serviços advocatícios extrajudiciais }\end{array}$ & \\
\hline
\end{tabular}

Fonte: elaboração própria.

Destaca-se a mudança de posicionamento da Ministra Nancy Andrighi, que em 2011, ao julgar o Recurso Especial nº 1.027.797/MS entendeu que os honorários convencionais integravam as perdas e danos de acordo com o previsto nos art. 389, 395 e 404, uma vez que apenas reintegrando esses valores ao vencedor da demanda estar-se-ia perfectibilizando a reparação integral do dano.

Porém, nos Embargos de Divergência no. 1.155.527/MG, a Ministra modificou seu posicionamento anterior, alinhando com o entendimento de que inexistia a obrigação de reembolso dos honorários advocatícios contratuais despendidos pela parte vencedora da demanda sob o fundamento de que o sintagma "honorários advocatícios" utilizado nos arts. 389, 395 e 404 deveria ser interpretado de forma a excluir os honorários contratuais relativos à atuação em juízo, uma vez que a esfera judicial possui mecanismo próprio de responsabilidade daquele que resulta vencido, ao obrigar este ao pagamento dos honorários sucumbenciais. Outrossim, o exercício do direito de ação ou de defesa não poderia ser considerado um ato ilícito e os honorários contratuais não poderiam ser judicialmente exigidos porque convencionados entre a parte e seu advogado, não podendo, assim, vincular terceiros, alheios a referido ajuste.

Entretanto, em 2019 a Ministra Nancy Andrighi, ao julgar o REsp. no. 1.703.356/MG - o qual não possui relação direta com a matéria alvo da investigação afirmou que "aquele que vence não deve sofrer prejuízo por causa do processo". Esse entendimento pode sugerir um retorno àquele que possuía em 2011.

\section{CONCLUSÃO}

Os honorários advocatícios contratuais possuem natureza jurídica distinta dos sucumbenciais, já que são decorrentes do próprio processo. E caso sejam suportados pela parte vencedora da demanda, representarão um prejuízo decorrente de um ato abusivo ilícito praticado pelo sucumbente. 
Os arts. 389, 395 e 404 combinados com o art. 927 e o caput do art. 944, todos do Código Civil, indicam que essa espécie de honorários representa parte das perdas e danos sofridos pela vítima do ilícito processual.

A pesquisa revelou que mesmo nas causas ajuizadas no âmbito dos Juizados Especiais Cíveis, bem como aquelas em que a parte está sob assistência judiciária gratuita, o sujeito que abusou de seu direito também é seria responsável por indenizar os custos que a parte vencedora teve com a contratação de advogado para atuar no processo. Em todos os casos, a tabela de honorários disponibilizada pela Ordem dos Advogados do Brasil funcionaria como referencial para estabelecimento desses honorários.

Entretanto, em que pese existir substrato legal e teórico suficiente para incluir os honorários contratuais como parcela das perdas e danos, a análise dos julgados do Superior Tribunal de Justiça revelou que o Tribunal tem, na grande maioria dos casos, entendido pela não existência dessa possibilidade, tendo como ratio juris o fato de que a condenação ao pagamento de honorários sucumbenciais também abrangeria os contratuais despendidos pelo vencedor. Além disso, para a maioria da Corte, a contratação de advogado para atuação judicial não caracterizaria ilícito passível de ressarcimento.

Assim, o STJ não contribui para a solução da problemática em que no Brasil se ganha perdendo, pois, para estar em juízo, a parte vencedora teve custos e prejuízos que não são cobertos pelos consectários da sucumbência, que sequer pertencerão a ela. Outrossim, a instância especial também não contribui para mitigar a compreensão ampla que se dá ao significado de acesso à justiça, que prejudica a eficiência do Judiciário.

\section{REFERÊNCIAS}

BRASIL. Lei ${ }^{\circ}$ 10.406, de 10 de janeiro de 2002. Institui o Código Civil. Brasília, DF: Presidência da República, 2002. Disponível em: http://www.planalto.gov.br/ccivil_03/leis/2002/110406compilada.htm. Acesso em: 5 maio 2020.

BRASIL. Lei no 13.105, de 16 de março de 2015. Código de Processo Civil. Brasília, DF: Presidência da República, 2015. Disponível em: http://www.planalto.gov.br/ccivil_03/_ato2015-2018/2015/lei/113105.htm. Acesso em: 6 JUN.2020.

CAHALI, Yussef Said. Honorários advocatícios. 3. ed. São Paulo: Revista dos Tribunais, 1997. 
O dever da parte sucumbente de indenizar a parte vencedora pelos prejuízos com o processo. Ou, é possivel ganhar sem perder?

CÂMARA, Alexandre Freitas. O Novo Processo Civil brasileiro. 4. ed. São Paulo: Atlas, 2018.

CARPENA, Heló́sa. O abuso de direito no Código Civil de 2002. Rio de Janeiro: Renovar, 2001.

CARVAlHO, Ivo César Barreto de. Análise dos aspectos civis e constitucionais do abuso de direito. Revista Opinião Jurídica, Fortaleza, v. 6, n. 10, p. 88-103, 2008.

CASTRO FILHO, José Olympio. Abuso de direito no processo civil. Rio de Janeiro: Forense, 1940.

CAVALIERI FILHO, Sergio. Programa de responsabilidade civil. 13. ed. São Paulo: Atlas, 2018.

CERQUEIRA, Társis Silva de. Acesso à justiça. Novíssima reflexão à luz dos processos repetitivos. Revista Opinião Jurídica, Fortaleza, v. 8, n. 12, p. 242-258, 2010.

CHIOVENDA, Giuseppe. Dell'azione nascente dal contratto preliminare. Saggi di Diritto Processuale Civile. Roma: Foro Italiano, 1930.

CHIOVENDA, Giuseppe. Instituições de direito processual civil. Campinas: Bookseller, 1998. 2 v.

CORDOPATRI, Francesco. La responsabilità processuale: profili storico-dogmatici. Roma: La Sapienza, 1991.

DINAMARCO, Candido Rangel. Instituições de direito processual civil. 9. ed. São Paulo: Malheiros, 2017.

DINAMARCO, Candido Rangel. Instituições de Direito Processual Civil. 5. ed. São Paulo: Malheiros, 2005. 2 v.

LIMA, Alcides Mendonça. Probidade processual e finalidade do processo. Uberaba: Vitória, 1978.

LOPEZ, Teresa Ancona. Exercício do direito e suas limitações: abuso de direito. In: NERY, Rosa Maria de Andrade; DONNINI, Rogério (coord.). Responsabilidade civil: estudos em homenagem ao Professor Rui Geraldo Camargo Viana. São Paulo: Revista dos Tribunais, 2009.

MAIA, Christianny Diógenes. Assessoria jurídica popular e acesso à justiça. Revista Opinião Jurídica, Fortaleza, v. 8, n. 12, p. 9-27, 2010.

NERY JUNIOR, Nelson. Teoria Geral dos Recursos. 6. ed. São Paulo: Revista dos Tribunais, 2004.

NERY JUNIOR, Nelson. Código Civil Comentado. 7. ed. São Paulo: Revista dos Tribunais, 2009.

NOGUEIRA, Antônio de Pádua Soubhie. Honorários advocatícios extrajudiciais. Revista Forense, v. 105, 2009.

88 - R. Opin. Jur., Fortaleza, ano 19, n. 30, p.63-90, jan./abr. 2021 
ONÓFRIO, Fernando Jacques. Manual de Honorários Advocatícios. São Paulo: Saraiva, 1998.

ORDEM DOS ADVOGADOS DO BRASIL (OAB). Código de ética e disciplina da OAB. Brasília-DF, 13 fev. 1995. Disponível em: https://www.oab.org.br/visualizador/19/codigo-de-etica-e-disciplina. Acesso em: 5 jul. 2020.

PINHO, Humberto Dalla Bernardina de; SALLES, Tatiana. Honorários advocatícios. Evolução histórica, atualidades e perspectivas no projeto do novo CPC. Revista Eletrônica de Direito Processual, Rio de Janeiro, v. 9, n. 9, p. 259-286, 2012.

PINTO, Nelson Luiz. Da natureza alimentar dos honorários advocatícios e da impossibilidade de imposição de sua compensação obrigatória a favor de partes diversas. Revista Eletrônica de Direito Processual, Rio de Janeiro, v. 14, n. 1, p. 468-472, 2019.

PONTES DE MIRANDA, Francisco Cavalcanti. Tratado de direito privado. Rio de Janeiro: Borsoi, 1966. t. LIII.

REDONDO, Bruno Garcia; MULLER, Julio Guilherme. Negócios processuais relativos a honorários advocatícios. Revista Eletrônica de Direito Processual, Rio de Janeiro, v. 16, n. 16, p. 58-76, 2015.

RIBEIRO, Fabio Mesquita. Possibilidade de reembolso de honorários contratuais não é pacífico. 2015. Disponível em: https://www.conjur.com.br/2015-set-18/fabio-ribeirohonorarios-contratuais-cabe-ou-nao-reembolso. Acesso em: 20 fev. 2020.

RODOVALHO, Thiago. Abuso de direito e direitos subjetivos. São Paulo: Revista dos Tribunais, 2012.

RODRIGUES, Rafael de Oliveira. O abuso do processo por intermédio da defesa heterotópica. Revista Eletrônica de Direito Processual, Rio de Janeiro, v. 8, n. 8, p. 850-867, 2011.

SANSEVERINO, Paulo de Tarso Vieira. Princípio da reparação integral: indenização no Código Civil. São Paulo: Saraiva, 2010.

SCAVONE JÚNIOR, Luiz Antonio. Do descumprimento das obrigações: conseqüências à luz do princípio da restituição integral. São Paulo: Juarez de Oliveira, 2007.

SILVESTRE, Gilberto Fachetti; LIMA NETO, Francisco Vieira. O abuso do poder de denunciar e o direito de não ser réu: uma leitura a partir do novo art. 28 do Código de Processo Penal (Lei no. 13.964/2019). Revista de Processo, São Paulo, v. 45, n. 307, p. 33-52, set. 2020.

THEODORO JÚNIOR, Humberto. Curso de Direito Processual Civil. 56. ed. Rio de Janeiro: Forense, 2015. 
O dever da parte sucumbente de indenizar a parte vencedora pelos prejuízos com o processo. Ou, é possivel ganhar sem perder?

THEODORO JÚNIOR, Humberto. Curso de Direito Processual Civil. 59. ed. Rio de Janeiro: Forense, 2018.

TRIGUEIRO, Victor Guedes; BORGES, João Paulo Resende. Análise econômica da litigância - pressupostos básicos e o Código de Processo Civil de 2015. Revista Eletrônica de Direito Processual, Rio de Janeiro, v. 20, n. 2, p. 313-338, maio/ago. 2019.

TUCCI, José Rogério Cruz e. A definição dos honorários advocatícios de sucumbência pelo STJ. 2019. Disponivel em: https://www.conjur.com.br/2019-fev-19/paradoxocorte-definicao-honorarios-advocaticios sucumbencia-stj. Acesso em: 24 jan. 2020.

WAMBIER, Luiz Rodrigues. Curso avançado de processo civil. 9. ed. São Paulo: Revista dos Tribunais, 2007.

ZANON JUNIOR, Orlando Luiz; SCHULZE, Clenio Jair. Apontamentos sobre honorários advocatícios. Revista Eletrônica de Direito Processual, Rio de Janeiro, v. 16, n. 16, p. 416-435, 2015.

\section{NOTA}

Declaramos que o artigo intitulado "O DEVER DA PARTE SUCUMBENTE DE INDENIZAR A PARTE VENCEDORA PELOS PREJUÍZOS COM O PROCESSO. OU, É POSSÍVEL GANHAR SEM PERDER?", submetido à Revista Opinião Jurídica, representa fruto das pesquisas desenvolvidas pelos autores no âmbito do Grupo de Pesquisa "Desafios do Processo" e do Programa Institucional de Iniciação Científica da Universidade Federal do Espírito Santo (UFES). Ambos os autores realizaram, concomitante, as tarefas de seu planejamento, execução e revisão da seguinte forma: GILBERTO FACHETTI SILVESTRE: planejamento metodológico; estruturação; indicação de bibliografia preliminar; construção da problemática e da hipótese; revisão da $1^{\text {a }}$ versão; apontamentos de aperfeiçoamento; revisão da $2^{\text {a }}$ versão; e FELIPE SARDENBERG GUIMARÃES TRÉS HENRIQUES: levantamento bibliográfico e documental; fichamentos; escrituração do texto; correção; elaboração da versão final. Por ser verdade, firmamos a presente em Cachoeiro de Itapemirim e Vitória, ambas no Estado do Espírito Santo, em 18 de setembro de 2020.

\section{Como citar este documento:}

SILVESTRE, Gilberto Fachetti; HENRIQUES, Felipe Sardenberg Guimarães Trés. O dever da parte sucumbente de indenizar a parte vencedora pelos prejuízos com o processo. Ou, é possível ganhar sem perder?. Revista Opinião Jurídica, Fortaleza, v. 19, n. 30, p. 63-90, jan./abr. 2021. 